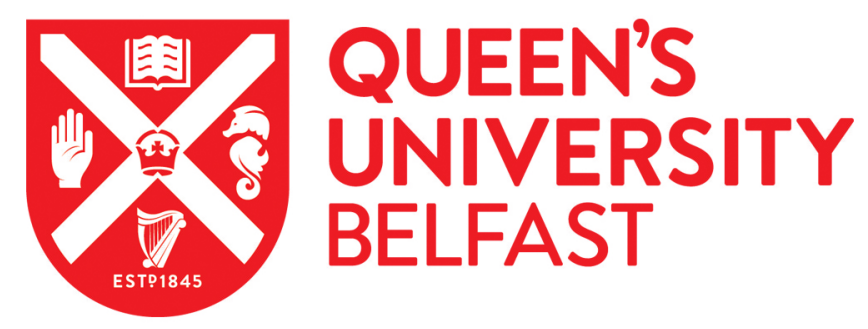

\title{
National assessment policy reform 14-16 and its consequences for young people: student views and experiences of GCSE reform in Northern Ireland and Wales
}

Barrance, R., \& Elwood, J. (2018). National assessment policy reform 14-16 and its consequences for young people: student views and experiences of GCSE reform in Northern Ireland and Wales. Assessment in Education Principles Policy and Practice, 25(3), 252-271. [https://doi.org/10.1080/0969594X.2017.1410465]. https://doi.org/10.1080/0969594X.2017.1410465

\section{Published in:}

Assessment in Education Principles Policy and Practice

\section{Document Version:}

Peer reviewed version

Queen's University Belfast - Research Portal:

Link to publication record in Queen's University Belfast Research Portal

\section{Publisher rights}

(c) 2017 Informa UK Limited, trading as Taylor \& Francis Group.

This work is made available online in accordance with the publisher's policies. Please refer to any applicable terms of use of the publisher.

\section{General rights}

Copyright for the publications made accessible via the Queen's University Belfast Research Portal is retained by the author(s) and / or other copyright owners and it is a condition of accessing these publications that users recognise and abide by the legal requirements associated with these rights.

Take down policy

The Research Portal is Queen's institutional repository that provides access to Queen's research output. Every effort has been made to ensure that content in the Research Portal does not infringe any person's rights, or applicable UK laws. If you discover content in the Research Portal that you believe breaches copyright or violates any law, please contact openaccess@qub.ac.uk. 


\title{
National assessment policy reform 14-16 and its consequences for young people: student views and experiences of GCSE reform in Northern Ireland and Wales
}

\author{
Rhian Barrance $^{1}$ and Jannette Elwood ${ }^{2}$ \\ ${ }^{1}$ School of Social Sciences, Cardiff University \\ ${ }^{2}$ School of Social Sciences, Education and Social Work, Queen's University Belfast \\ (corresponding author) \\ barrancer@cardiff.ac.uk; j.elwood@qub.ac.uk
}

\begin{abstract}
This paper uses data from a mixed-methods research project which explored the views and experiences of students in Northern Ireland and Wales on the assessment and reform of GCSEs. The research found that while students were generally supportive of the substance of the reforms in each region, they raised concerns about the rapid pace of reform, and questioned whether changes were in their best interests. Participants expressed particular anxiety about the end of three-country regulation of GCSEs and the consequences of this development for students. As those most affected by changes to qualifications, they wanted a greater role in determining national assessment policies. Considering the impact of such reforms on young people, and recognising the important perspectives they can offer on how qualifications are enacted in practice, it is argued that the concept of student voice should be broadened to accommodate young people's involvement in national assessment and educational decisions.
\end{abstract}

Keywords: Assessment policy reform; student views; GCSEs; student voice; qualifications 


\section{Biographical information}

Rhian Barrance is a researcher in education and social sciences at the Wales Institute for Social and Economic Research Data and Methods (WISERD), a research institute at Cardiff University. Prior to joining WISERD, she completed her PhD in Education at Queen's University Belfast.

Jannette Elwood is Professor of Education at the School of Social Sciences, Education and Social Work at Queen's University Belfast. She is Academic Director at Queen's of the Northern Ireland and North East (NINE) ESRC Doctoral Training Programme. She is also Vice President of the Association for Educational Assessment- Europe.

\section{Funding}

Rhian Barrance received a doctoral scholarship to complete the research for this project from the Department of Education Northern Ireland.

\section{Disclosures}

No disclosures to report. 


\section{Introduction}

GCSEs are the main examinations taken by students at age 16 in England, Northern Ireland (NI) and Wales. Since their inception in 1988, GCSEs have been a 'common' examination (Gipps et al., 1986), jointly regulated by governments in these regions. However, this all came to an abrupt end in 2013, following a series of policy disagreements between England, Northern Ireland and Wales regarding plans for GCSE reform. The consequence is that while the label of 'GCSE' is used across the three regions, for the first time there are differences in the ways that students can achieve the qualification, which has major implications for the portability of GCSEs across England, Northern Ireland and Wales - meaning that qualifications obtained in one region many not be seen as equal currency in another. This paper considers a significant gap in the educational assessment and policy literature by focusing on the consequences of assessment policy reform from the perspectives of students, particularly in this case from students in Northern Ireland and Wales. While some existing research addresses students' views or experiences of particular assessment techniques, it is rare for their perspectives on assessment policy and/or its reform to be given consideration (Elwood et al., 2017). It is argued that not only do young people have a right for their views to be given due weight on public policy issues that affect them, but also that they have notable perspectives which can make an important contribution to our understanding of assessment policy implementation and success (Elwood, 2013).

The paper situates the debates around assessment policy reform within the context of devolved government arrangements for assessment and qualifications policy. The central UK government has devolved particular public policy responsibilities to the separate jurisdictions of the UK (England, Northern Ireland, Wales and Scotland ${ }^{3}$ ). Such a context of devolved

\footnotetext{
${ }^{3}$ Scotland is not considered in this paper as it has its own curriculum and assessment systems and also the project reported on focused on Northern Ireland and Wales with specific comparison to England as all three jurisdictions support GCSEs
} 
policy making locates assessment policy reform within contexts of complex local processes driven by a range of different and competing factors and influences which force difficult decisions about the adequacy and appropriateness of existing assessment arrangements for local needs (Raffe \& Spours, 2007). It also highlights how different priorities and ideological positions on the purposes of education are articulated through assessment reform programmes (Cadwallader \& Tremain, 2013). So for example, while the significant changes taking place in England tend to emphasise the role of qualifications for school accountability measures (Gove, 2013), those taking place in Northern Ireland and Wales tend to focus more on the principles of inclusion and motivation (CCEA, 2013; Welsh Government, 2012), suggesting a greater emphasis on the needs of learners for the local contexts within which they are being educated. However, most of the rhetoric around these policy positions ignores the views of those most affected by them. This paper considers these assertions about the values inherent in qualification reform through a critical lens, by considering whether students in Northern Ireland and Wales perceive the current reforms as relevant and in their best interests.

\section{Context: GCSE Policy Reform across England, Northern Ireland and}

\section{Wales}

In recent years there has emerged an interesting situation where students in England, Northern Ireland and Wales are studying for the same qualification, labelled 'GCSE' but their experience of these qualifications are very different depending on where students live and on their teachers' choice of examination specifications and awarding organisations. This examination will no longer be common between the students who take it.

Until recently GCSEs were regulated on a three country basis: there was collaboration between Ofqual, the regulatory body for England, the Welsh Government, and the Council for Curriculum, Examinations and Assessment (CCEA), the qualifications regulator for 
Northern Ireland. However, from 2010, political and educational disagreements regarding the fundamental purposes and quality of GCSEs emerged, and by 2013 they forced the collapse of three-country regulation. Since then, major (but not the same) reforms to GCSEs have been implemented in England, Northern Ireland and Wales. The consequence is that for the first time there are differences in the ways that students can achieve a GCSE across the three regions.

\section{Reform of GCSEs: England}

In May 2010 a coalition UK government between the Conservative and Liberal Democratic parties was formed and the centrepiece of its education agenda was a concentration on reforming qualifications to make sure that 'existing qualifications are rigorous, challenging and properly prepare our young people for life, work and study' (Gibb, 2010). To meet the criteria of 'rigorous and challenging', the Department for Education in England specifically expressed concern about the structure of national examinations, notably course structures (modularity vs. linearity) and resits. They also raised concern about the use of early entry possibilities, where students are entered for some elements of the examinations in earlier sittings rather than all at the end of the two-year course. Both resits and early entry were practices seen as ways in which schools sought to raise examination outcomes and better their performance measures for accountability systems (Department for Education, 2010). Since 2012 the following major changes have been rolled out with regard to GCSEs in England: substantive reviews of syllabus content for core subjects to make GCSEs more rigorous; the re-introduction of linear qualifications (taken wholly at the end of a course) assessed solely by examinations; the removal of controlled assessment (internal to the school) in particular subjects; limitations to the number and extent of resits; and the introduction of a numerical grading scale at GCSE (9-1) for mathematics and English in 2017 and then rolled out to all subjects in subsequent years. Moreover, restrictions on tiering in GCSEs have also been 
introduced. This is a form of differentiation used to provide examination papers of appropriate levels of challenge for all students. For those subjects that use tiering at GCSE there are normally two tiers with exam papers covering differing syllabus content and varied in cognitive demand - the higher tier with associated grades $A^{*}-\mathrm{D}$ (9 to 4$)$, and the foundation tier, with associated grades C-G (5-1). Following the latest reforms, tiering has been removed from most subjects.

\section{Reform of GCSEs: Northern Ireland}

Northern Ireland has diverged from England in its sated purposes of reform, by focusing on preparation for life and developing young people's skills, rather than the outcomes of assessments for accountability (CCEA, 2013: 2). The initial policy approach undertaken in Northern Ireland was based on the principle of flexibility and portability was considered a key concern (Perry, 2013); to have examinations equivalent in 'currency' in all aspects to their peers in England and Wales. This was because a large proportion of students from Northern Ireland enrol on university courses in England, with $22 \%$ of undergraduates doing so in 2011 (HESA, 2013). Northern Ireland schools can choose syllabuses from English and Welsh awarding organisations as well as modular or linear qualifications, which means that they are not restricted to Northern Ireland qualifications only (O’Dowd, 2014). While modular GCSEs remain an option for those studying in Northern Ireland, only one resit opportunity is now allowed per unit (DENI, 2014). Moreover, the use of controlled assessment and tiering has also been reduced (DENI, 2014). Furthermore, Northern Ireland qualifications have retained the letter grading scale $\left(A^{*}-\mathrm{G}\right)$ and introduced a $\mathrm{C}^{*}$ grade to provide equivalency for the grade 5 to be used in England (Weir, 2016).

\section{Reform of GCSEs: Wales}


Decisions about reforms from the Welsh Government were based on 'the best interests of learners' (Welsh Government, 2012, p.2) and were not 'allowed to simply emerge through a series of reactions to events or decisions in England' (ibid. p. 18). This statement reflects suggestions generally that the business of governance in the UK's devolved administrations primarily consists of deciding whether or not to adopt policies developed in England (Fitz, 2000) and particularly that Wales's policy-making post-devolution has been criticised for focusing too much on distinguishing itself from England (Reynolds, 2008). However, even given these criticisms, Wales's approach to qualification reform has differed markedly to that in England, and reflects more those decisions taken in Northern Ireland. Thus in Wales: both modular and linear course structures are now used; decisions about course structure, controlled assessment and tiering have been retained but it is emphasised that they should be used 'only where there is a clear case for doing so' (Welsh Government, 2012: 48); limited resits are now allowed per unit; generally early entries in to GCSEs are discouraged; and the current $\mathrm{A}^{*}$-C grade structure has been retained (Welsh Government, 2014).

\section{Issues in assessment and qualifications policy reform}

In recent years a once relatively everyday area of education provision (national examinations), overseen by awarding organisations in direct communication with schools has become a significant policy frontline (Baird, 2011). Policy proliferation has become more problematic through multiple reforms being carried out in haste because of governments' general desire to have measurable impact on education within electoral terms (Baird \& LeeKelley, 2009). In relation to changes in examination systems, while governments may want to see quick results that show considerable changes in standards and practices, tight 
timescales can pose significant threats to the validity of examinations (Cadwallader \& Tremain, 2013), with insufficient time being allocated to certain stages of the work (e.g. curriculum development, identification of assessment criteria), instability creeping in to the system because of mass change all at once, and possible adverse consequences for students due to changes being introduced live without piloting (Elwood, 2012; 2013; Oates, 2007). Many of the problems experienced within assessment policy reform can be attributed to the increased politicised nature of reform programmes, and the expectation on examination results to fulfil multiple purposes (e.g. individual grades for students, performance measures for teachers and schools) (Cadwallader \& Tremain, 2013). Such problems compound the underlying problems in the design of examination systems, impacting on both the reliability and the validity of the final product as well as a lack of clarity over what is expected of key stakeholders (Baird \& Coxell, 2009).

In practice, patterns emerge in assessment reform that show results on examinations dipping suddenly when new tests are introduced then improving slowly once teachers and students develop a better understanding of the assessment requirements. Over subsequent assessment sessions results tend to reach a plateau when teachers and students become very familiar with procedures and changes begin to show less variation (Koretz, 2005); performance tending to plateau after approximately three years (Ofqual, 2016). This pattern has been described as the 'sawtooth' effect (e.g. Koretz \& Barron, 1998; Koretz, 2005; Linn, 1998, 2000). Research around this effect in the UK shows that performances on reformed qualifications are affected in similar ways (Cresswell, 2003; Ofqual, 2015). What is of interest within this current paper, are the repercussions for those students who take the new qualifications in the first year of the reforms. If results dip following major changes to qualifications then what are the consequences for students in terms of grades awarded and the impact of lower than expected 
grades on future life chances ${ }^{4}$. Elwood (2013) emphasises that it is students who disproportionately suffer the effects of successive changes which appear to be driven by ‘ideological and political agendas’ (p. 109). Consequently, Elwood (2013) suggests that young people should have a greater role in the development of qualification policy, to ensure that any reforms really are in their best interests as well as providing crucial information about the ways in which reforms are enacted in practice.

\section{Students as public policy actors}

Conceptualisations of students as public policy actors call for young people to have their views taken into account in policy decisions that affect them and to be afforded greater opportunities to participate in political life at the public level (Arnott, 2008; Hinton et al., 2008; Tisdall, 2008). A commonly cited reason for involving children in public policy is their right to participation under article 12 of the UNCRC, which asserts children's rights to participate in decisions which affect them (United Nations, 1989; see also Lundy, 2007). While the UNCRC has been influential and has driven much research in the area of children and participation, the drive for children to be recognised as public policy actors is not only made on a legal basis. As users of public policy, children are affected by reforms to public institutions and policies, and so, it is argued, they should be given the opportunity to participate in decisions regarding change and development (Tisdall, 2008). Underlying this is a shift in perceptions of young people as having the capacity to give valid insights on institutions and services (Arnott, 2008).

In relation to assessment, there have been calls for test-takers' rights to be taken seriously, in light of potential negative repercussions of testing, as well as significant power imbalances

\footnotetext{
${ }^{4}$ At the time of writing (May 2017) exam regulators in the UK, in attempting to deal with anticipated problems caused by the Sawtoowth effect, have committed to using year-on-year 'comparable outcomes' to ameliorate any dips in results following the introduction of new qualifications (McDowell, 2017).
} 
between test-takers and highly influential global testing organisations (Shohamy, 2001). Moreover, more democratic assessments which involve users in their production have been proposed (Shohamy, 2001). Furthermore, Pavlou (2008) has suggested that adult test-takers' consumer rights should also be considered. However, these rights are limited as they pertain to adults and to those designated as 'consumers' which is not often the case with children. The UNCRC designates children as rights holders and as such demands that 'the best interests of the child' guide decisions with regard to public policy actions that affect children and young people directly (Elwood \& Lundy, 2010: 335). With regard to assessment it has been argued that those devising national testing systems should abide by the UNCRC's core principles and take positive action to ensure that young people's views are taken into account in assessment decisions (Elwood \& Lundy, 2010).

\section{Student voice and assessment policy}

While the inclusion of young people in policy decision-making is limited at the national level, there are well-established arguments for their inclusion in decisions at a local level within their own educational settings. This work is situated within that on 'student voice' which refers to practices that have repositioned the worth of students' unique perspectives on teaching, learning and schooling more generally (Cook-Sather 2006). Such work has included student participation in: school-level policy decisions (Thompson, 2011; Whitty and Wisby, 2007); teaching and learning decisions at the classroom level (Morgan, 2009); schoollevel committees alongside teachers and governors (Osberg et al., 2006); advisory groups for research projects with university researchers (Fielding, 2001); and in school and national councils focusing on key aspects of educational life (Davies and Yamashita, 2009).

However, there are shortcomings associated with the work around student voice reflecting the tendency to perceive some students' voices to be representative of all others (Bragg, 2007; 
Thomson, 2011) and assumptions that all student forums are effective and operating normally. Problems with ineffective student bodies can generate scepticism about voice initiatives among students themselves (Alderson, 2000) and indeed can be seen as mechanisms to reinforce student compliance (Fielding and McGregor, 2005). Furthermore, assumptions about a single 'student voice' denies diversity and difference in students' needs and opinions, hiding hierarchies of power and privilege within and across different student groupings (Cook-Sather, 2006). While keeping these limitations in mind many calls have been made over the years for changes in mind-sets, structures and power relations, to support respectful dialogue between students and adults in educational spheres. Such calls have emphasised the potential for student voice to enhance understanding of the impacts and effects of educational policies and practices as they are played out at both institutional and national level (Cook-Sather, 2002; Cullingford, 1991; Fielding, 2001).

More recently, educational assessment research has also highlighted the importance of listening to students' experiences as an essential component of understanding the impact of national assessment systems (especially those at school-leaving age) on young people (e.g. Baird et al., 2010; Banks \& Smyth, 2015; Chamberlain, 2012; Daly et al., 2012; Elwood, 2012; Elwood et al., 2015). Hodgson \& Spours (2003, p. 92) highlighted students feeling like 'guinea pigs' because of problems associated with reforms to national assessment programmes which play a highly significant role in young people's lives. Moreover, these studies have provided understandings of students' views on issues pertinent to assessment development such as variations in (un)reliable marking (Chamberlain, 2012), grade inflation and falling standards (Elwood, 2012) and implementing policy changes directly into 'live' examinations (Daly et al., 2012). Furthermore, this research has revealed a sense of disempowerment amongst young people in their lack of influence over 'higher level decisions' (Elwood, 2013, p.108) and that 'ultimately they were the ones most affected if 
qualifications systems fail due to instabilities around syllabus and grading changes during examination cycles (Elwood, 2013, p. 108).

Emerging out of some of the studies considered above is a limited realisation by awarding organisations and regulators of the need to include students as participants in some of their own consultations into assessment reform (CCEA, 2013; Welsh Government, 2012; YouGov 2017). Consultations like these present influential audiences for young people's views to be heard. However, as Elwood (2012) has emphasised, it is often difficult to determine the amount of influence young people have compared to other stakeholders in such consultations. While the involvement of young people is encouraging, it is clear that there is still a great deal to be done.

This paper aims to contribute to progress being made in this area by presenting the views and experiences of young people in the jurisdictions of Northern Ireland and Wales. The vast majority of the research around these issues derives from the English context, and yet the deviations between England, Northern Ireland and Wales in their approaches to GCSE reform set out an interesting case in relation to multiple changes across jurisdictions to ostensibly the same examination. Such changes, we believed, required further investigation.

\section{Methodology}

This paper draws on an original dataset of Northern Irish and Welsh students' views and experiences of GCSEs from a large mixed-methods research project (see Elwood, 2017). The methods employed within the study consisted of focus groups (20) conducted with GCSE students aged 15-16 across Northern Ireland and Wales (10 in each jurisdiction; 5-10 participants in each group) as well as a questionnaire survey completed by 1600 GCSE students (901in Wales; 699 in Northern Ireland). The research aims were to seek out students' views about a range of different issues relating to GCSEs and their reform, such as 
the extent to which they were consulted about qualification reform and their opinions on the recent changes to qualifications in their regions. A particularly innovative aspect of the research instrument development was that it was designed in collaboration with groups of GCSE students who acted as advisors to the research. Working with students in this way reflected a direct children's rights approach to the research (Lundy \& McEvoy, 2012) which aims to build young people's capacity within the topics under consideration so that they can act as advisors on issues relating directly to the research and to the lives of children and young people. In this case capacity building sessions were delivered for advisory group members in NI and Wales on the purpose of assessment and reforms to GCSEs, as well as research processes such as survey design and data analysis and interpretation. It was important to take such an approach to ensure that the questions asked of the wider student participants were comprehensible, sensible and relevant to them as well as addressing issues that they themselves felt were important to ask of their peers. Moreover, the advisory groups' advice was key in formulating the capacity-building information, such as infographics on reforms, which were used in the questionnaires. This enabled students to give informed answers to questions, which was important, as very few participants in the focus groups were aware of the changes before the research visit.

Quantitative data from the survey was analysed using SPSS to identify relationships between key variables and patterns of responses of interest to the overall aims. Qualitative data was (i) coded by hand if it came from the open-ended questions on the survey and (ii) transcribed and coded using MAXQDA if it was from the focus groups. In analysing the data, the advisory group members were also involved in looking at anonymised extracts of qualitative data to help code and arrange into themes. Such a process offers new perspectives on ways in which the data can be considered, enhancing the quality of the analysis and the credibility of the findings with young people (Lundy et al., 2011). Students' analysis supported the 
researchers' interpretations, and helped inform the development of overall emerging themes from the data. While this paper will use both the quantitative and qualitative data to present key findings, it primarily focuses on the latter in order for the reader to 'hear' the voices of the young people and their views and experiences of GCSEs more generally. We present what were perceived to be the main issues for them in relation to qualification reform, their views on the changes to the GCSE within the devolved policy contexts as well as the impact of the removal of a common GCSE examination.

\section{Presentation of the data}

In the presentation of the data below, all extracts are labelled with information about the institution attended by students, the data source from which the extract is derived, e.g. focus group (FG) or open ended question on the survey. Additionally, the region, e.g. Northern Ireland (NI) or Wales will be identified. Where only one student is quoted, the gender will be indicated. The names of all institutions have been replaced with pseudonyms.

\section{Students' perspectives on qualification reforms in Northern Ireland and}

\section{Wales}

\section{Assessment structures and formats}

As discussed earlier, wide ranging changes to GCSEs have come into play in England, Northern Ireland and Wales including the reduction on the use of controlled assessment, modularity and tiering. These changes have come about after only a few years after their introduction in 2009 (DCSF, 2008) and have been implemented in relative haste given government timeframes for change within parliamentary sessions.

In relation to what students thought about these changes, the survey data suggested that, on the whole, students in NI and Wales were relatively supportive of the decisions taken by the 
governments in their regions in relation to the reform of assessment structures and formats. With regards to the decision made in both NI and Wales to retain modularity, at least for some subjects, most students were in favour of keeping modular courses. In fact, as shown in Table 1 below, the majority of students wanted a choice to be available for all, or for only modular courses to be permitted. Very few students preferred the approach taken in England to mandate that all courses be linear.

Table 1 about here

Likewise, the majority of participants in both regions agreed with their governments' plans to retain controlled assessment (see Table 2). While it was clear that many students had reservations or were unsure about controlled assessment due to the high levels selecting 'neither agree nor disagree', only around a tenth of participants indicated that they disagreed with the policy.

Table 2 about here

Approval for the decision to retain tiering was also high, with over two thirds agreeing with their governments' plans in both regions (see Table 3 below).

Table 3 about here

While there was reasonably high support for the qualification policies taken by NI and Wales, the focus group data showed that students had concerns about a number of issues emerging from these changes relating as well as their exclusion from the policy process. They were apprehensive about the impact of numerous reforms, and in particular, the consequences of the loss of a 'common' GCSE examination (from the end of three country regulation) for their future educational and employment opportunities. These will be discussed further below. 


\section{Awareness of reforms and impact}

From discussions with students in focus groups, there was not a great deal of awareness amongst students about the most recent decisions taken regarding GCSEs, but that many were knowledgeable about previous reforms or had a sense that there had been a number of changes to GCSEs over the last few years. For example, when given information about the current reforms, a student in Northern Ireland asked: 'Has it not been changed a good few times... has it not been chopping and changing?' (Male, Devlin High, FG 2, NI). In both regions there was concern about the amount of change in the system and the impact it could have upon individuals, with one NI student noting that 'GCSEs are the way of having that achievement [to show] what you're good at, but this will not happen if it changes every time' (Female, Paulin High, Survey, NI). In Wales, this point was made even more emphatically, with students discussing their cohort as 'a test year' for new reforms (Female, Herbert High, FG 2), and another group discussing their experience as akin to being experimented upon:

S1: it's too much development like every year

S2: we're just an experiment for the next year basically

INTERVIEWER: an experiment for the next year?

S1: guinea pigs (Waters High, FG, Wales)

There was a sense of disempowerment amongst participants, with students expressing the view that they have no control over the reform process and that decisions are not made in their best interests. In describing themselves as being experimented upon, they echo research which has considered the problem of visiting unpiloted reforms on young people (Oates, 2007). They also resonate with the statements made by young people interviewed by Hodgson and Spours (2003) regarding the reform of A-levels in 2002, who also likened themselves to 'guinea pigs', suggesting that little has changed with regards to the ways that students experience qualification reform in the UK over the last decade and a half.

Some students went into more detail about the problems caused by reforms, noting that it was difficult to understand what was expected of them when new specifications were introduced:

'I do not agree with the exam boards changing the style of their examinations because this sometimes gives us no indication on what to expect in the GCSE exam.'(Male, Follett High, Survey, Wales) 
Such statements resonate with research that shows lack of familiarity with new styles of assessment or the requirements of examinations can have a significant impact in the early years of the assessment (Ofqual, 2016). It shows that students can experience problems in understanding the requirements of new specifications and course types, emphasising again possible detrimental repercussions for young people of making changes to 'live' national systems.

Students' responses indicated that they were not only concerned about the immediate consequences for the students in the cohorts who will sit these new qualifications but also the impact on all year groups, causing problems with inter-cohort comparability. This was a key issue for the participants in this study, with students revealing anxiety about the consequences of the changes on many cohorts of young people:

\section{S1: they change too much}

S2: like the differences between when our parents did it when our siblings did it and then now when we are doing it they just change all the time

S3: they're changing by the year and it's hard

\section{S4: they all mean different things}

S1: like the English exam last year was new so the English exam we are doing now our teachers know what to do but last year it just changed so everyone in last year failed or most of them (Waters High, FG, Wales)

Students were aware that they would not only be competing against pupils in their own year groups for educational and employment opportunities in the future, but with others from additional cohorts. They found this lack of consistency in assessment features across year groups concerning, especially if employers did not have sound knowledge of the different assessment arrangements in place for different cohorts, and therefore those who sat more challenging examinations could be disadvantaged.

I think if it was done then it would have to be like people who are like interviewing you would have to sort of know how you sort of sat the exam like how your exams are set and everything and you they sort of knew more about it than just you got you got an A (Male, Herbert High, FG 2)

Thus students considered wide-ranging implications for young people generally with respect to these new reforms. The range of significant consequences emerging from recent changes 
created for them a level of instability in the system that was difficult to understand. Students expressed anxieties about the impact and pace of change, seeing those being implemented at the time of the research as simply more change in a steady stream of changes, all of which contributed to problems in how their qualifications would be viewed by selectors for courses and jobs.

\section{End of a 'common' GCSE: loss of three country regulation and students' particular concerns}

When GCSE was first introduced in 1988, it was described as a common examination for all students (Gipps et. al., 1986). While over the years small differences in specifications might have been apparent, the GCSE maintained a common framework and approach across all three jurisdictions, who worked together to maintain comparability of standards, assessment criteria, awarding practices and stability of the examination. However the new GCSEs coming on stream no longer look the same nor are structured in the same way. This present situation regarding regulation and the 'look' and 'feel' of the GCSE was one particular aspect of the recent reforms which concerned students to a significant extent. A particularly pertinent issue for students in Northern Ireland was the portability of the new qualifications, perhaps reflecting the fact that a relatively high proportion of students from this region apply for university in England (HESA, 2013). In the focus groups, concern was expressed by those who were considering applying for university or for jobs in England:

You'd almost worry that like if you ever wanted to try and get a job in England or anything that they would consider like a Northern Irish GCSE to be less relevant than an English one or somehow like insufficient (Female Heaney Grammar, FG 2, NI)

For participants, changes to the ways that the GCSE was now to be assessed resulted in differences in the skill-sets required to achieve good grades under very different assessment structures, raising questions about the fairness and validity of the qualifications across the 
three jurisdictions. For example, there was a perception that modular qualifications in Northern Ireland would not be perceived to be rigorous enough compared to linear qualifications in England, and that NI students would be disadvantaged as a result. The view in both NI and Wales was that standardisation of qualifications across all regions would be best for all students: 'I think all of Britain should just have the same course so if you're going for jobs it's equal (Female, Sheers High).

Welsh students also raised concerns about the comparability of the GCSEs that they were studying compared with those in England which was perceived to have a more challenging assessment system:

in England more people will be smarter because... they're doing it all at the end ... where we're getting it easier cause we get controlled assessments to do over and over again (Male, Waters High, FG, Wales)

it's a GCSE so if in three nations who are all taking the GCSE why isn't it the same as standard?' (Male, Herbert High, FG 3, Wales).

This is particularly pertinent for Welsh students with the land border between them and England, with some of their peers being educated across the border in England and taking very 'different' GCSEs. The data here suggests that while students are relatively supportive of modular courses, controlled assessment and tiering, they do not see decisions to remove or retain these features of GCSEs in isolation and balance these decisions with considerations about portability and comparability. Students were extremely concerned at what they saw as decisions which would, in the long term, affect the value of the qualifications they receive as well as their 'currency' in an ever competitive education and employment market. Overall, students seem to prefer adaptations to the current system; tweaks rather than extreme changes. In many cases they suggest that problems within assessment systems could be solved by giving students a greater role in determining how they are enacted. It is often not the assessment feature itself that it is perceived to be problematic, but the way it is enacted and the fact that students are not routinely involved in decisions about them. We turn to this issue next.

\section{Students' involvement in assessment policy-making}


Some students attributed the problems in the examination system to politicians' failure to consult them before reforms were implemented. For example, at Sheers High in Wales, one student stated that 'I think politicians just say right we're going to do this because I think it's a really good idea just give me more votes... but they don't get feedback when they make decisions...' (Male, Sheers High, FG, Wales). There was a sense that reforms were sometimes made for political reasons, to win votes, and that the opinions of stakeholders such as young people were thus not considered relevant to the debates:

S1: but I think all of Britain should just have the same courses... cause I think Wales are overcomplicating it

S2: yeah they're trying to be independent with other countries

S3: yeah they're trying to be independent and it's not benefitting us I don't think

S2: it's benefitting the politicians because like they gain popularity but it doesn't really benefit us in any way because

(Sheers High, FG, Wales)

Here students' views reflect previous research on the politicised nature of assessment policy reform (Baird, 2011; Cadwallader \& Tremain; 2013; Elwood, 2013) and a sense that the best interests of young people were not prioritised in the reforms. In a focus group discussion in Northern Ireland, it was argued that the government has 'made a system that's not suitable [and] they didn't know until they put it into practice. They need to know what we think so they know how to adjust it to suit the needs of the best from the youth' (Male, Friel High, FG, NI). For students, they expressed a sense of injustice that mistakes were made because of students' exclusion from the policy process. There were two reasons for this. First, because students' perspectives would help politicians understand how policies are being enacted in practice. The data on students' experiences of GCSE reform emerging from this project supports this view, showing that qualification features such as controlled assessment and modular courses are enacted in very different ways within different contexts (Barrance \& 
Elwood, 2018 in press). Thus students suggested that information on their experiences would be of benefit to politicians' understanding of the process of policy-making as a whole.

Second, the data suggests that by consulting young people, governments can ensure that the qualification system developed reflects what students, as the main users of GCSEs, want from them. This could improve their utilitarian value and create a more fair system as choice and diversity of learning would be taken into account, rather than a 'one size fits all' approach.

There was a strong sense that students' views should be taken into account because they are the ones who are most affected by changes to qualifications:

because if it's affecting you - and like other students surely you should be the one to have a say in the decisions? (Female, Heaney Grammar, FG 1, NI).

Student views on this issue accord with those expressed in the literature on student voice and children as policy participants (discussed earlier). These literatures argue that young people should be consulted because they have a legal right to participation in decisions that affect them (Lundy, 2007), and that without their views policy-makers will not have a complete picture of how their policies will work in practice (Cook-Sather, 2002; Tisdall, 2008).

These findings are also reflected in the quantitative data deriving from the survey. Students were asked 'how much are you asked your opinion about issues relating to GCSEs, such as those asked during this survey?' The results can be seen in Table 4 below:

Table 4 about here

As can be seen, the majority of participants in both regions indicated that they were not consulted, or were but only minimally. Moreover, most of the responses in the open-ended box which asked them to give details of who consulted them referred to parents or teachers 
and none referred to national governmental bodies, which indicates that their views had not been collected systematically by such organisations.

While the results of this question suggest that consultation with students on GCSE reforms is not routine, when asked whether they should be asked their opinions about GCSEs, the results were overwhelming positive. Over $90 \%$ of students in both regions agreed that students should be consulted on these kinds of issues before changes are introduced. On the whole, there was frustration over how decisions were being made currently by people who were not directly affected by the reforms and a belief that students themselves should have a greater involvement in policy-making. In focus groups from both NI and Wales, students offered ideas for facilitating students' participation in GCSE policy making:

S1: I think maybe there should be a big vote on it

S2: ... what's the point in a bunch of people who have went through education... all politicians, arguing, except young people [...]

S3: well I think you'd have to ask the people who are about to go to do GCSEs - ones in like third year - give them all the options

S4: they may not know

S1: that's why you have to explain it to them, give them all the options...

S2: they wouldn't get the absolute 100 per cent final decision

S1: But they'd have an input (Longley High, FG 1, NI)

S1:...it's us we're doing it

S2: I think we should be taken into account

S1: I think that there should be more of these [focus groups]

S2: I feel like it's older people making our decisions when we are the ones being affected by it (Waters High, FG, Wales) 
In both these cases, students have suggested that students' views should be taken into account, one through a democratic process which helps politicians understand students' views, and another through more consultations such as the focus groups they were participating in. Elwood $(2012 ; 2013)$ and Elwood \& Lundy (2010) have called for a shift in approaches from both governments and awarding organisations as to how they engage with young people on matters of assessment reform and development; the findings from this study support this call with students clearly articulating perspectives on how this could be operationalised. Notably, the views here are not that students should dictate policy, but that they should have 'an input' and that their views should be 'taken into account', as in keeping with Article 12 of the UNCRC (United Nations, 1989). Moreover, by arguing that young people have a valid contribution to make to the debate on reform, with active participation by adults in providing information and guidance, a considerable shift in the understanding of policy makers, awarding organisations, teachers and school leaders as to the value that listening to young people on these matters can bring, especially to creating sustainable and fair assessment systems.

\section{Discussion and concluding remarks}

This research has shown that students are able to provide powerful insights on GCSE assessments both across structures and formats as well as how national systems of assessment are enacted within local schools and institutions. These insights have the potential to enhance our understanding of the ways in which national assessment systems are understood by those affected by them most; strengthening the case for the inclusion of students' views in policy making in qualification reform. The idea that students should be involved in discussions regarding assessment is not new; it is a central principle of formative assessment, fostering students' engagement and active participation in their learning (Hayward, 2013). However, 
what is new from this research, is the strength of concern from students about their lack of involvement in higher-level decisions at a national level regarding changes to key summative assessments that determine their life chances and future opportunities. These findings challenge the view that students should not be consulted on assessment and qualification policies. They show young people with the capacity to make considered judgements and who do not automatically opt for what they perceive as the easiest option. It suggests that perhaps many of the arguments made against consulting young people are based on unfair assumptions about what young people will say; a perpetuation by adults of what Grace (1991, p.202) termed the 'ideology of immaturity'. Cullingford (1991) articulated very clearly that young people are aware of the huge potential they offer adults in understanding educational issues but that their huge potential continues to go untapped. This is especially so in this research where young people do not see a valuing, by adults, of the potential of their contributions to informing high-risk policy domains such as educational assessment reform. Students presented constructive ideas as to the ways in which they and their teachers could navigate the myriad of decisions about assessment at this level; they expressed clear wishes to be involved in both national and school-level determinations regarding GCSEs so that decisions made are in their best interests which they feel is not the case at present. Students were sceptical, not so much about what the actual changes were to GCSEs, but about their governments' reasons for introducing the latest reforms. They suggested that decisions were made for political reasons rather than educational ones, reflecting previous research on the politicised nature of policy-making in educational assessment (Cadwallader \& Tremain, 2013). Thus, a sense of powerlessness emanated from students' responses through criticisms made about the lack of consultation with young people on these matters. Cullingford (1991) eloquently details how young people are conscious of, observe, and discuss, the nature of power and influence in their own educational settings; they may not overtly describe what 
they observe and discuss as such, but they are aware of the politics of the social organisations within which they move. In the same vein, students were able to articulate an awareness that the changes introduced would affect them most, and as such 'power', in the guise of decisionmaking, should be shared with them, especially with regard to future systems. The majority of students were unaware of all of the changes to GCSEs, and yet they argued that, as the ones most affected by the reforms, they should be involved in making decisions regarding future assessment policies.

It is important to emphasise that students tended to agree with the substance of their governments' plans regarding changes to GCSEs; if not their reasoning for them. This is possibly because the reforms to GCSEs in NI and Wales were less radical than those introduced in England, and students tended to approve of the assessment system they were experiencing at the time of the research. The main problem, as students saw it, was that all these changes would remove the 'common GCSE' across the three jurisdictions with all the problems of comparability and portability which this raised. Students were concerned about how their different 'GCSEs' would now be viewed by HE institutions and future employers and the impact of variations in understanding for their future options. At the time of the research, there was less awareness about the changes also to the labelling of GCSE results (91 in England; and the retention of $\mathrm{A}^{*-\mathrm{G}}$ in $\mathrm{NI}$ and Wales) but concerns about this have emerged from other later studies (see YouGov, 2017). Students expressed concern about the nature of policy-making in devolved regions, which they suggested were designed to differentiate policies in their regions from those of England, resonating with suggestions in the policy literature that Wales's main concern is to distinguish itself from England (Reynolds, 2008). While participants tended to agree with the reforms themselves, it was their lack of any role in contributing to them that was problematic. In common with policymaking in other fields, it may be that a more collaborative model of policy-making (Raffe 
and Spours, 2007) with greater involvement of young people in decision-making may have engendered more support amongst young people for the reforms being implemented.

The results of this project are comparable with those detailed in the literature section above that show students as having the capacity to express valid opinions on complex assessment issues (Chamberlain, 2012; Daly, 2012; Elwood, 2012; 2013; Barrance, 2017). In this particular context they showed a strong understanding of how GCSE assessment structures and practices are experienced by them within schools and colleges. Such findings contribute to education policy research that considers policy as being 'enacted' (Ball et al., 2012) rather than implemented, showing how students experience assessment reforms in a myriad of ways depending on their locations, schools, teachers and their own interpretation of events.

Students may not have a formal role in assessment policy-making, but as this data has shown they are at the centre of the enacted policies and processes in their local contexts and their 'lived social participation across all the spheres of their [assessment] interactions (Horgan et al, 2017, p. 275). In this respect they are as much 'policy actors' (Ball et al, 2012) as their teachers or school leaders with significant influence over the interpretation and implementation of assessment policy changes.

Findings from this research have the potential to contribute to the field of assessment research by showing that it is very easy to make assumptions about how assessment policy is enacted within institutions, without considering that the practice will be quite different from what we expect. There will be differences in how students experience assessment policy reform and it is these differences that should be made visible to inform both national and international policies as well as institutional practices. The data from this and other studies (Elwood, 2012; Barrance, 2017) highlight how young people feel positioned within assessment regimes and how considering their perspectives on these matters can only improve our knowledge of fundamental assessment practices 
The results of this study suggest that the notion of 'student voice' needs to be expanded to accommodate not only the multiple 'voices' of students within educational settings (CookSather, 2002) but also the involvement of multiple student voices in national decision-making (Tisdall, 2008) regarding assessment policy. We argue that it is problematic that assessment decisions at both school and national levels tend to be discussed separately, with little recognition of the fluidity between national and local assessment policy. Broadening the concept of student voice to encompass students' participation in national decisions would also allow for a recognition of the diverse ways in which national governmental policies are enacted in different contexts (Ball et al., 2012), thus enabling a more fruitful, holistic discussion of policies and their impacts, based on students' accounts. By combining reflections from key concepts in the fields of student voice (Cook-Sather, 2002), children as public policy actors (Tisdall, 2008), and children's rights (Barrance, 2017; Elwood \& Lundy, 2010), we can arrive at a far more nuanced conceptualisation of the experience of national assessment as it is perceived and experienced by young people. 


\section{References}

Alderson, P. (2000). School students' views on school councils and daily life at

school. Children \& Society, 14, 121-134. doi: 10.1111/j.1099-0860.2000.tb00160.x

Arnott, M. (2008). Public policy, governance and participation in the UK: A space for children? International Journal of Children's Rights, 16, 355-367.

doi:10.1163/157181808x311196

Baird, J. (2011, March). Implementing examinations policy: How many hands make heavy work. Inaugural Professorial Lecture, University of Bristol, UK.

Baird, J., Author, Duffy, G., Feiler, A., O’Boyle, A., Rose, J., Stobart, G., \& McWhirter, A. (2010). 14-19 centre research study: Educational reform in schools and colleges in England. Annual report. Retrieved from OUCEA: http://oucea.education.ox.ac.uk/wordpress/wpcontent/uploads/2013/04/CReSt-Annual-Report-Final-whole.pdf

Baird, J., \& Coxell, A. (2009). Policy, latent error and systemic examination failures, CADMO, 17, 105-122. doi:10.3280/CAD2009-002011

Baird, J., \& Lee-Kelley, L. (2009). The dearth of managerialism in implementation of national examinations policy. Journal of Education Policy, 24, 55-81. doi:10.1080/02680930802382938

Ball, S. (2015). What is policy? 21 years later: Reflections on the possibilities of policy research. Discourse: Studies in the Cultural Politics of Education, 36, 306-313. doi: $10.1080 / 01596306.2015 .1015279$ 
Ball, S., Maguire, M., \& Braun, A. (2012). How schools do policy: Policy enactments in secondary schools. London: Routledge.

Banks, J., \& Smyth, E. (2015). 'Your whole life depends on it': Academic stress and highstakes testing in Ireland. Journal of Youth Studies, 18, 598-616.

doi:10.1080/13676261.2014.992317

Barrance, R. (2017). The assessment and reform of GCSEs: The views and experiences of young people in Northern Ireland and Wales (Unpublished doctoral dissertation). Queen's University Belfast, Belfast.

Barrance, R., \& Elwood, J. (2017). Inequalities and the curriculum: Young people's views on choice and fairness through their experiences of curriculum as examination specifications at GCSE. CLS Working Paper. London: Institute of Education, UCL.

Bragg, S. (2007). 'Student voice' and governmentality: The production of enterprising subjects? Discourse: Studies in the Cultural Politics of Education, 28, 343-358. doi:10.1080/01596300701458905

Cadwallader, S., \& Tremain, K. (2013). How policy formation and implementation interacts with risks to high stakes qualifications. Retrieved from CERP: https://cerp.aqa.org.uk/sites/default/files/pdf_upload/CERP_RP_SMC_25102013.pdf Chamberlain, S. (2012). Public perceptions of reliability. In D. Opposs \& Q. He (Eds.), Ofqual's Reliability Compendium (pp. 691-725). Coventry: Office of Qualifications and Examinations Regulation.

Cook-Sather, A. (2002). Authorizing students' perspectives: Toward trust, dialogue, and change in education. Educational Researcher, 31, 3-14. doi:10.3102/0013189X031004003 
Cook-Sather, A. (2006). Sound, presence, and power: "student voice" in educational research and reform. Curriculum Inquiry, 36, 359-390.

Council for the Curriculum, Examinations and Assessment (2013). Review of GCSE and Alevel qualifications: final report with appendices. Retrieved from CCEA:

http://ccea.org.uk/sites/default/files/docs/accreditation/projects/review/final_report.pdf.

Cresswell, M. (2003). Heaps, prototypes and ethics: The consequences of using judgements of student performance to set examination standards in a time of change. London: University of London Institute of Education.

Cullingford, C. (1991). The Inner World of the School: Children's Ideas about School. London: Cassell.

Daly, A., Baird, J., Chamberlain, S., \& Meadows, M. (2012). Assessment reform: students' and teachers' responses to the introduction of stretch and challenge at A-level. Curriculum Journal, 23, 139-155. doi: 10.1080/09585176.2012.678683

Department of Children, Schools and Families (2008). Delivering 14-19 reform: Next steps. Retrieved from National Archives:

http://webarchive.nationalarchives.gov.uk/20130401151715/http://www.education.gov.uk/pu blications/eOrderingDownload/7928-DCSF-Delivering\%2014-

19\%20Reform\%20Summary.pdf

Davies, L., \& Yamashita, H. (2009). Students as professionals: The London secondary school councils action research project. In B. Percy-Smith, \& N. Thomas (Eds.), A handbook of children and young people's participation (pp. 230-239). London: Routledge. 
Department for Education (2010). The importance of teaching: Schools white paper.

Retrieved from Department for Education: https://www.gov.uk/government/publications/theimportance-of-teaching-the-schools-white-paper-2010.

Department of Education Northern Ireland (2014). Recommendations on the fundamental review of GCSEs and A-levels. Retrieved from Department for Education Northern Ireland: https://www.education-ni.gov.uk/publications/recommendations-fundamental-review-gcsesand-levels

Elwood, J. (2012). Qualifications, examinations and assessment: Views and perspectives of students in the 14-19 phase on policy and practice. Cambridge Journal of Education, 42, 497-512. doi:10.1080/0305764X.2012.733347

Elwood, J. (2013). The role(s) of student voice in 14-19 education policy reform: Reflections on consultation and participation. London Review of Education, 11, 97-111. doi:10.1080/14748460.2013.799807

Elwood, J., Hopfenbeck, T., \& Baird, J. (2017). Predictability in high-stakes examinations: Students' perspectives on a perennial assessment dilemma. Research Papers in Education, 32:1, 1-17. doi: 10.1080/02671522.2015.1086015

Elwood, J., \& Lundy, L. (2010). Revisioning assessment through a children's rights approach: Implications for policy, process and practice. Research Papers in Education, 25, 335-353. doi:10.1080/02671522.2010.498150

Fielding, M. (2001). Students as radical agents of change. Journal of Educational Change, 2, 123-141. doi:10.1023/A:1017949213447

Fielding, M., \& McGregor, J. (2005). Deconstructing student voice: New spaces for dialogue or new opportunities for surveillance. Montreal: AERA. 
Fitz, J. (2000). Governance and identity: The case of Wales. In R. Daugherty, R. Phillips, \& G. Rees (Eds.), Education policy-making in Wales: Explorations in devolved governance (pp. 24-46). Cardiff: University of Wales Press.

Gibb, N. (2010). Press release: Government announces changes to qualifications and the curriculum. Retrieved from Gov.uk: https://www.gov.uk/government/news/government$\underline{\text { announces-changes-to-qualifications-and-the-curriculum }}$

Gipps, C. (1986). The GCSE: An uncommon examination. London: Institute of Education.

Gove, M. (2013). Ofqual policy steer letter: Reforming Key Stage 4 qualifications. Retrieved from Gov.uk: http://media.education.gov.uk/assets/files/pdf/l/ofqual\%20letter.pdf

Grace, G. (1995). School Leadership: Beyond Education Management. London: The Falmer Press.

Hayward, L. (2013). From why to why not? The conundrum of including learners' perspectives: A response to this Special Issue. London Review of Education, 11, 184-189. doi:10.1080/14748460.2013.799814

Higher Education Statistics Authority (2013) Higher education student enrolments and qualifications obtained at higher education institutions in the United Kingdom for the academic year 2011/12. Retrieved from HESA:

https://www.hesa.ac.uk/index.php?option=com_content\&view=article\&id=2667

Hinton, R., Tisdall, E.K., Gallagher, M., \& Elsley, S. (2008). Children's and young people's participation in public decision-making. The International Journal of Children's Rights, 16, 281-284. doi:10.1163/157181808X311132 
Hodgson, A., \& Spours, K. (2003). Beyond A levels: Curriculum 2000 and the reform of 1419 qualifications. London: Kogan Page.

Koretz, D. (2005). Alignment, high stakes, and the inflation of test scores. In J. Herman and E. Haertel (Eds.), Uses and misuses of data in accountability testing. Yearbook of the National Society for the Study of Education. 104, Part 2, 99-118. Malden, MA: Blackwell Publishing. doi: 10.1111/j.1744-7984.2005.00027.x

Koretz, D., \& Barron, S. (1998). The Validity of Gains on the Kentucky Instructional Results Information System (KIRIS) (MR-1014-EDU). Santa Monica: RAND. Retrieved from RAND: http://www.rand.org/pubs/monograph_reports/MR1014.html

Linn, R. (1998). Assessments and accountability (CSE Technical Report 490).

Los Angeles, CA.: National Center for Research on Evaluation. Retrieved from ERIC: https://eric.ed.gov/?q=Assessments+and+Accountability\&ff1=autLinn, +Robert+L $. \& \mathrm{id}=\mathrm{ED} 443865$

Linn, R. (2000). Assessments and accountability. Educational Researcher, 29, 4-16. doi:10.3102/0013189X029002004

Lundy, L. (2007). 'Voice' is not enough: Conceptualising article 12 of the United Nations Convention on the Rights of the Child. British Educational Research Journal, 33, 927-942. doi: 10.1080/01411920701657033

Lundy, L., \& McEvoy, L. (2012). Children's rights and research processes: Assisting children to (in)formed views. Childhood, 19, 129-144. doi:10.1177/0907568211409078

Lundy, L., McEvoy, L., \& Byrne, B. (2011). Working with young children as co-researchers: An approach informed by the United Nations Convention on the Rights of the Child. Early Education \& Development, 22, 714-736. doi:10.1080/10409289.2011.596463 
McDowell, B. (2017) Personal communication.

Morgan, B. (2009). 'I think it's about the teacher feeding off our minds, instead of us learning off them, sort of like switching the process around': Pupils' perspectives on being consulted about classroom teaching and learning. The Curriculum Journal, 20, 389-407.

doi:10.1080/09585170903424922

O'Dowd, J. (2014). Oral statement on evaluation and assessment. Retrieved from CCEA: http://ccea.org.uk/sites/default/files/docs/news/2014/Mar/statement__evaluation_and_assessment_-_tuesday_11_march_2014.pdf

Oates, T. (2007). Protecting the innocent: The need for ethical frameworks within mass educational innovation. In L. Saunders (Ed.), Educational research and policy-making: Exploring the border country between research and policy (pp. 144-174). Oxford: Routledge.

Ofqual (2015). New GCSE grading structure. Retrieved from Ofqual:

https://www.gov.uk/government/uploads/system/uploads/attachment_data/file/460142/new_g cse_grading_structure.pdf.

Ofqual (2016). An Investigation into the 'Sawtooth Effect' in GCSE and AS/A Level Assessments (Ofqual/16/6098). Retrieved from Ofqual: https://www.gov.uk/government/uploads/system/uploads/attachment_data/file/549686/aninvestigation-into-the-sawtooth-effect-in-gcse-as-and-a-level-assessments.pdf Osberg, J., Pope, D., \& Galloway, M. (2006). Students matter in school reform: Leaving fingerprints and becoming leaders. International Journal of Leadership in Education, 9, 329343. doi:10.1080/13603120600895338

Pavlou, P. (2008). Consumer's rights and language testing. Retrieved from ealta.eu.org: http://www.ealta.eu.org/conference/2008/docs/saturday/Pavlou\%20LT\%20and\%20CR.pdf 
Perry, C. (2013). GCSE and A-level reform: research and information service research paper. Retrieved from NI Assembly:

http://www.niassembly.gov.uk/globalassets/documents/raise/publications/2013/education/114 13.pdf

Raffe, D., \& Spours, K. (2007). Policy-making and policy learning in 14-19

education. London: University of London, Institute of Education.

Reynolds, D. (2008). New Labour, education and Wales: The devolution decade. Oxford Review of Education, 34, 753-765. doi:10.1080/03054980802519019

Shohamy, E. (2001). The power of tests: a critical perspective on the uses of language tests. London, Pearson.

Thomson, P. (2011). Coming to terms with 'voice'. In G. Czerniawski \& W. Kidd (Eds.), The international handbook of student voice (pp. 19-30). Bingley: Emerald.

Tisdall, E. (2008). Is the honeymoon over? Children and young people's participation in public decision-making. The International Journal of Children's Rights, 16, 419-429. doi: $10.1163 / 157181808 X 311240$

United Nations (1989). United Nations Convention on the Rights of the Child (UNCRC). Retrieved from United Nations: http://www.ohchr.org/en/professionalinterest/pages/crc.aspx Weir, P (2016) Oral statement on qualification market and grading. 28 June 2016. Retrieved from CCEA.org:

http://ccea.org.uk/sites/default/files/docs/news/2016/Jun/minister_oral_statement_on_grading _june16.pdf 
Welsh Government (2012). Review of qualifications for 14 to 19-year-olds in Wales: Final report and recommendations (CAD/GM/0227). Retrieved from Welsh Government:

http://gov.wales/docs/dcells/publications/121127reviewofqualificationsen.pdf

Welsh Government (2014). Qualified for life: How qualifications in Wales are changing. Retrieved from Welsh Government:

http://learning.gov.wales/docs/learningwales/publications/140616-qualified-for-life-howqualifications-in-wales-are-changing-en.pdf

Whitty, G., \& Wisby, E. (2007). Whose voice? An exploration of the current policy interest in pupil involvement in school decision-making. International Studies in Sociology of Education, 17, 303-319. doi:10.1080/09620210701543957

YouGov (2017). Perceptions of A levels, GCSEs and other qualifications in England - Wave 15. An Ofqual commissioned report (Ofqual/17/6193). Retrieved from Gov.uk:

https://www.gov.uk/government/uploads/system/uploads/attachment_data/file/606463/Ofqual _Perceptions_Survey_Wave_15_Report.pdf 
Table 1: Respondents' views on their government's plans to allow both modular and linear GCSE courses, by region

\begin{tabular}{|l|c|c|c|}
\hline Region & $\begin{array}{c}\text { Only modular } \\
\text { courses should be } \\
\text { allowed \% }\end{array}$ & $\begin{array}{c}\text { Only linear courses should } \\
\text { be allowed \% }\end{array}$ & $\begin{array}{c}\text { Both linear and } \\
\text { modular courses should } \\
\text { be allowed \% }\end{array}$ \\
\hline NI $(n=575)$ & 39.1 & 7.7 & 53.2 \\
\hline Wales $(n=783)$ & 28.0 & 9.7 & 62.3 \\
\hline
\end{tabular}

Table 2: Respondents' level of agreement with their government's plans to keep controlled assessment, by region

\begin{tabular}{|l|c|c|c|}
\hline Region & Disagree \% & $\begin{array}{c}\text { Neither agree nor } \\
\text { disagree \% }\end{array}$ & Agree \% \\
\hline NI $(n=579)$ & 10.4 & 15.7 & 74.0 \\
\hline Wales $(n=788)$ & 12.4 & 28.2 & 59.4 \\
\hline
\end{tabular}

Table 3: Respondents' level of agreement with their government's plans to retain tiering, by region

\begin{tabular}{|l|c|c|c|}
\hline Region & Disagree \% & $\begin{array}{c}\text { Neither agree nor } \\
\text { disagree \% }\end{array}$ & Agree \% \\
\hline NI $(n=578)$ & 6.4 & 13.1 & 80.5 \\
\hline Wales $(n=788)$ & 10.2 & 24.2 & 65.5 \\
\hline
\end{tabular}

Table 4: Percentages of students' according to the amount they report being asked about changes to GCSEs, by region

\begin{tabular}{|l|l|l|l|l|}
\hline Region & Not at all \% & A little \% & Quite a bit \% & A lot \% \\
\hline NI (n=571) & 33.5 & 35.6 & 21.2 & 9.8 \\
\hline Wales $(n=771)$ & 36.3 & 42.5 & 14.4 & 6.7 \\
\hline
\end{tabular}


